\title{
$\mathrm{TiAl}$ 金属間化合物の繰返し酸化特性
}

清水哲也*, 飯久保知人**, 磯部 晋*

\section{Cyclic Oxidation Resistance of TiAl Intermetallic Compounds}

Tetsuya Shimizu, Tomohito Iikubo and Susumu Isobe

\begin{abstract}
Synopsis
The oxidation behavior of Ti-33.5mass\% $\mathrm{Al}$ with small additions of $\mathrm{Ni}, \mathrm{B}$ and $\mathrm{Si}$ was investigated from $700^{\circ} \mathrm{C}$ to $1000^{\circ} \mathrm{C}$ in air. The cyclic oxidation resistance of the binary TiAl is excellent up to $800{ }^{\circ}$, but beyond it the outer nodular $\mathrm{TiO}_{2}$ layer is spalled with inner protective $\mathrm{Al}_{2} \mathrm{O}_{3}$ film and so the oxidation behavior progresses in a linear law. The addition of $\mathrm{Si}$ takes effective in improving the cyclic oxidation resistance of TiAl, and the additions of $\mathrm{B}$ and $\mathrm{Ni}$ are ineffective.
\end{abstract}

\section{1. 腥}

$\mathrm{L} 1$ 型楧造の金属間化合物の一つである TiAl は、低密度で優れた高温強度を有するため軽量耐 熱材料として期待されている1。

しかし、TiAlの実用化に当たっては、室温延性 および耐酸化性とい52 項目について改善が必要 である。

単純な TiAl の室温延性は $1 \%$ 末満であり、信 頼性を向上するには少なくとも延性を数\%に向上 させる必要がある。現在この面に関しては、第 3 元素の添加2) 、4、組織調整5゙どによる改善が因ら れており、3\%近い室温延性が得られている。

一方耐酸化性についても、近年、多くの報告が なされており、それらによれば、TiAl 自身の酸化 は800 $\mathrm{C}$ 以上で急速に進むこと、そのとき形成され るスケールは、 $\mathrm{TiO}_{2}$ と $\mathrm{Al}_{2} \mathrm{O}_{3}$ の幾つかの周から成

1991年 9 月 4 日受付

*大同特殊鋼研究闰発本部

“”大同特殊鋼姝研究開発本部, 工博
る複雑な構造を有することが判っている6゙,文。また $\mathrm{Si}^{(8)}, \mathrm{Mo}^{9)}, \mathrm{Nb}^{n}, \mathrm{~W}^{7)}, \mathrm{P}^{(0)}+$ \& 、耐酸化性の向上に 有効な元素す明らかになってきている。しかし、 これらの報告の多くは、連続的な酸化特性の報告 のみであり、熱サイクル下での酸化特性、すなわ ち綝返し酸化特性については言及されてない。

綝返し酸化特性は、酸化スケール表面処理居を 構成する層と、TiAl 母材との熱膨張率の相違から 生じる熱応力による、スケール内の割れの発生や、 表面層の耐侱離性を評価することであり、実際に 耐熱部品への使用を考えた場合、極めて重要な特 性値である。

そこで本研究では、 $\mathrm{TiAl}$ 金属間化合物の実用化 の基礎とするために、単純二元系とそれに延性向 上に有奻といわれている B, Niおよび耐酸化性 向上元粠である Si を添加した実験材について絽 り返しを含む高温酸化特性を調査した。

\section{2. 実 臤 方 法}

\section{1 供践材}

Table 1 に示す 5 種の化学成分の TiAl をブラ 
ズマ・スカル炉により容製し、直径約 $100 \mathrm{~mm}$ 、重 量約 8kg の鋳塊を得た。ベースの TA 材の $\mathrm{Al}$ 含 有量は $\mathrm{Ti}$ と $\mathrm{Al}$ が 1 ：1の化学量論組成となる $36 \mathrm{wt} \%$ とした。非平衡凝固により生成した $\mathrm{Ti}_{3} \mathrm{Al}$ と TiAl の鋳造二相組織を、TiAl 単相とするため に、鋳塊に1 200C、5 時間の均質化処理を施した。 均筫化処理後の光学影微鏡組織を Photo. 1 に示 す。各材料とも、この処理によりにほ単相になっ ている。 $\mathrm{Ni} ， \mathrm{~B} ， \mathrm{Si}$ が単独/椱合添加されている TN 材、TB材、TNB材およびTNBS 材の 4 種 は、ミク口組織をみる限りでは、いずれす特に析 出物は認められない。

酸化試験片は、すべて厚さ $3 \mathrm{~mm} 、$ 幅 $10 \mathrm{~mm}$ 、長 さ25mm の短冊状とし、均質化処理した鋳塊から 放電切断により切り出した。その後、表面処理を

Table 1. Chemical compositions of experimental materials.

\begin{tabular}{|c|c|c|c|c|c|}
\hline No. & $\mathrm{Ti}$ & $\mathrm{Al}$ & $\mathrm{Ni}$ & B & $\mathrm{Si}$ \\
\hline TA & \multirow{5}{*}{ Bal. } & 36.10 & - & - & - \\
\hline TN & & 35.88 & 0.29 & - & - \\
\hline TB & & 36.08 & - & 0.04 & - \\
\hline TNB & & 36.27 & 0.37 & 0.06 & - \\
\hline TNBS & & 35.58 & 0.34 & 0.05 & 0.22 \\
\hline
\end{tabular}

施するのを除き、表面をエメリー紙で順次研磨し て、最終1000番で仕上げた。これをてセトンで脱 脂洗浄した後、寸法と重量を測定し酸化試験に供 した。な和比較材として Table 2 に示す $\mathrm{Ni}$ 基耐

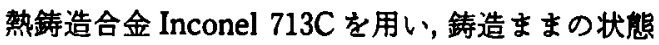
で上記と同様の試歌片を作製した。

\section{2 酸化試験}

\subsection{1 臬続酸化試験}

繰返し酸化挙動と比數するため、TA 材につい ては連続酸化の挙動す調查した。試験は Fig. 1 に 示すよらな、試験片を吊した透明石英製ルッボを、 㹂型管状シリコニット炉内で加熱することにより 行った。試験温度は、 $700^{\circ} \mathrm{C} 、 800^{\circ} \mathrm{C} 、 850^{\circ} \mathrm{C} 、 900^{\circ} \mathrm{C}$ 、 $1000^{\circ} \mathrm{C}$ の 5 水準とし、加熱時間96時間の条件で実 施した。なお、試験中は温度範囲が設定温度の士

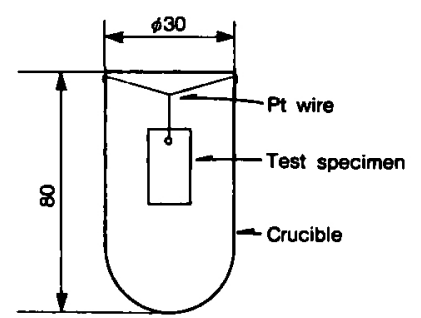

Fig. 1. Test specimen and the crucible.

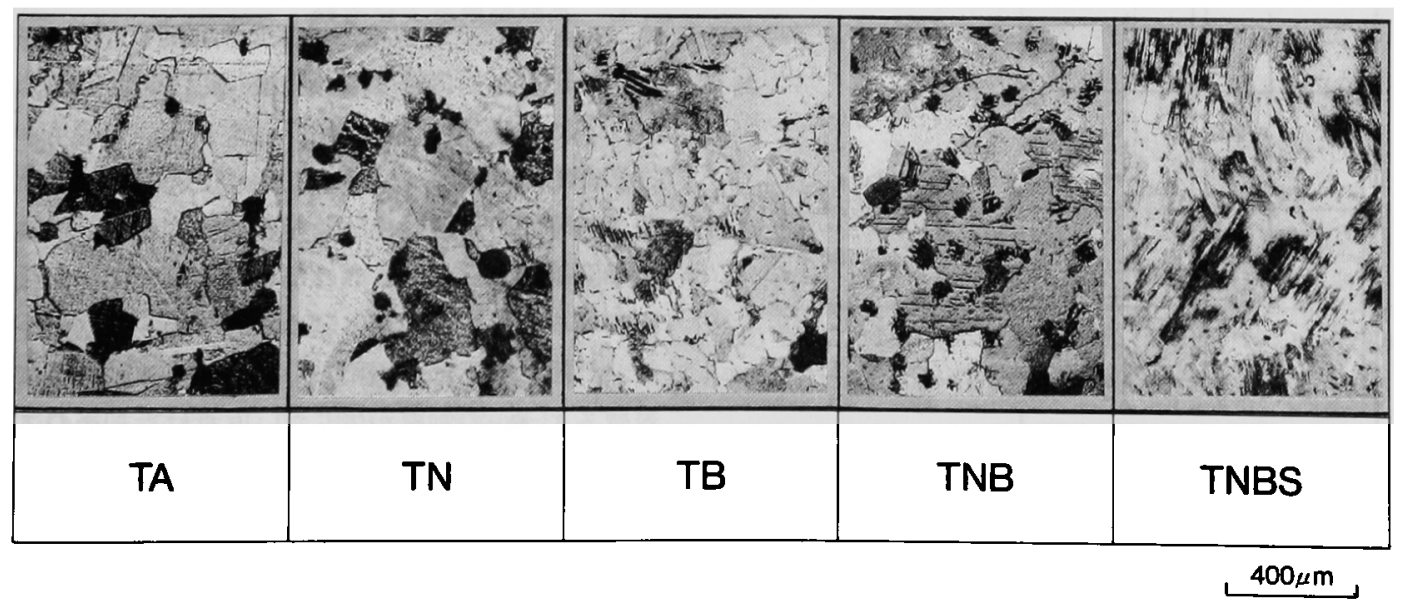

Photo. 1. Microstructure homogenized at $1200^{\circ} \mathrm{C}$ for $5 \mathrm{~h}$. 
$1 \%$ 以下になるよらに炬温を制御した。

今回の試脍では、各試験での策件がなるべくー 定となるよらに、察囲気のコントロールを行った。 純度 $99.9 \%$ の合成空気を、純水が入った 3 個の 300 $\mathrm{ml}$ のビーカーの中へ、流速 $0.1 \mathrm{~cm} / \mathrm{sec} て ゙$ 通気させ た後に、妒内人送り込んた。。このとき路点が20C となるよらに、ビーカー内の水温を調節した。 たビーカーから妒内までの配管が結露することを 防ぐために、この部分には、コードヒーターを巻 き、露点以上の温度に加熱した。

試跧の開始は昇温した炉内に試呀片を挿入後、 军囲気温度が試監温度士 1 \%の幅に再度昇温した 時点とした。試唋後はスケールがルッボの外に我 散しないように、試験片を取り出した後、直ちに フルミナ製ルッボで蓋をし、デシヶーター内で自 然冷却した。また、 $900^{\circ} \mathrm{C}$ の試験については、酸化 量の释時変化を把握するために、上記の試験と同 じ雾囲気内において熱天科による测定す実施し た。

\subsection{2 繰返し酸化試検}

本試験は、Fig. 2 に示すような、雾囲気の制御が

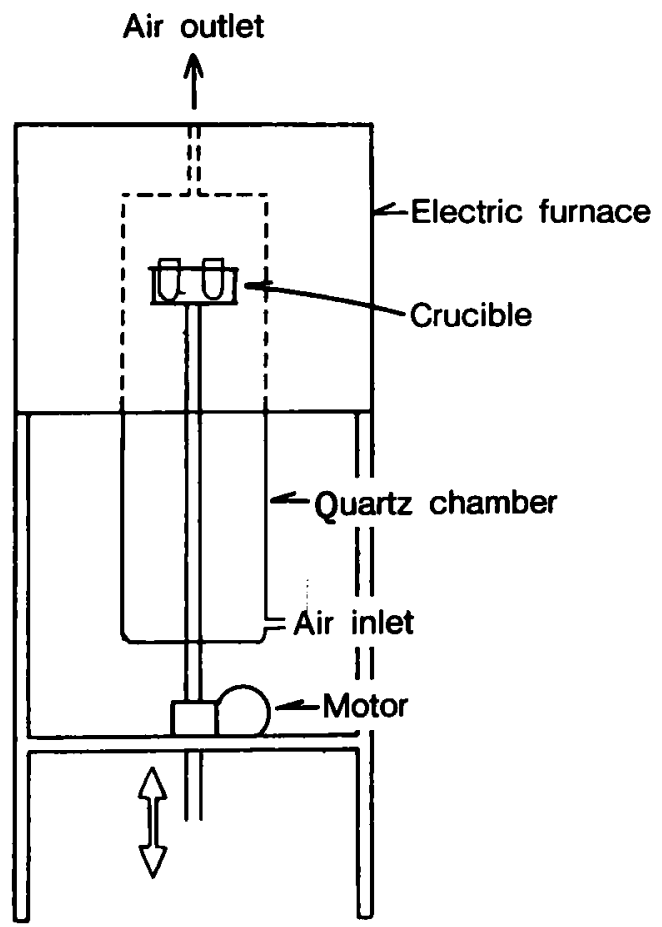

Fig. 2. The apparatus for cyclic oxidation test.
できる、試験片年降装置のついた㹂型カンタル妒 を使用して行った。試験温度は、TA材では700兄 および900ㄷの 2 水準で、その他の試料では、900 の 1 水準で、それぞれ加熱保持時間30分、1 1 サイ クル60分の条件で実施した。加熱保持時間は、其 温時試験片の温度が試辆温度の土 $1 \%$ 以内に入。 た時点を開始時間とし、この時点から30分間保持 した。繰り返し数は、加熱時間の合計が連続酸化 試験と同じ96時間となるように192サイクルとし た。なお途中、12サイクル、24サイクル、48サイ クルおよび96サイクルです試検片を取り出し酸化 増量の湘定を行った。

军囲気は、連続酸化試験と同じ方法により制御

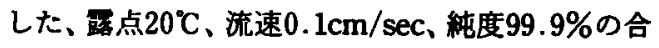
成空気中とした。

\section{3 表層スケールの锶泰}

酸化状態ならびに酸化機構の検討のために、試 検啳、試検片表居横断面のミク口観察と成分分析 を実施し、さらに試験片表面のスケールと制離ス ケールの同定を行った。

ミク口観察は、走查型電子䫒微鏡 (SEM：日立 製 S 800）を用い、加速電圧 $20 \mathrm{kV}$ で行っだ。成分 分析は SEM に付属のエネルギー分散型分析装置 （EDX）を用いて主に実施した。一部の試蜍片で は、波長分散型の EPMA をあわせて用いた。

スケールのX線回折による同定は、リガク製回 転陰荳型X線回折装置（ロータ・フレックス）で $\mathrm{CoK}$ 線を用いて、出力 $40 \mathrm{kV} \times 80 \mathrm{~mA}$ の条件で実 施した。

\section{3. 実医結果およU゙考察}

\section{$3.1 \mathrm{TA}$ 材の高温酸化特性}

\section{1 .1 連綂酸化特性}

Photo. 2 にTA 材 $9700^{\circ} \mathrm{C} ら 1000^{\circ} \mathrm{C} に お け$ る、96時間の連続酸化試験後の外観を示す。試験 終了直後の高温状態における目視覞察では、全温 度ともスヶールの制離は認められなかった。しか し、試験後の冷却過程において、一部の試険片に 表居スケールの别離が生じた。写真は冷却後のス ケールが剝離した状態を示したすのである。

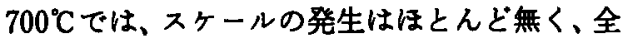
面が黒色を呈している。800C以上では表面スヶー

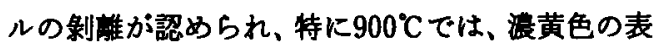
面スケールがほ忹全面にわたって荆離している。 


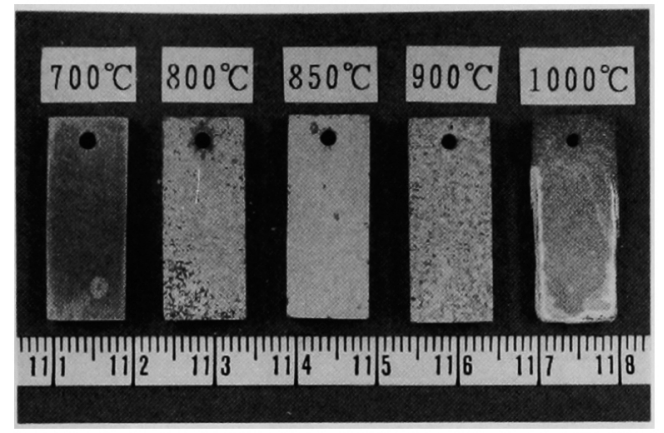

Photo. 2. Test specimens of TA after isothermal oxidation for $96 \mathrm{~h}$.

Table 2. Chemical composition of Inconel 713C.

(wt\%)

\begin{tabular}{c|c|c|c|c|c|c}
\hline $\mathrm{C}$ & $\mathrm{Si}$ & $\mathrm{Mn}$ & $\mathrm{P}$ & $\mathrm{S}$ & $\mathrm{Ni}$ & $\mathrm{Cr}$ \\
\hline 0.12 & 0.04 & $<0.02$ & 0.005 & 0.002 & $\mathrm{Bal}$. & 12.78 \\
\hline \hline $\mathrm{Mo}$ & $\mathrm{Al}$ & $\mathrm{Ti}$ & $\mathrm{Nb}$ & $\mathrm{B}$ & $\mathrm{Zr}$ & $\mathrm{Fe}$ \\
\hline 4.00 & 6.18 & 0.81 & 2.17 & 0.010 & 0.08 & 0.58 \\
\hline
\end{tabular}

$800^{\circ} \mathrm{C} 、 850^{\circ} \mathrm{C}$ で表面の淡黄色から黄色のスケー

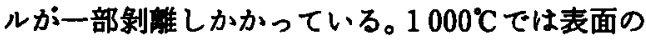
褐色をしたスケールの内、コーナー部などの熱応 力の高い部分で豩離が起こっており、その部分で は薄菒から白色のスケールが観察される。

Fig. 3 にこれらの酸化増量を示す。700Cの酸化 増量は、実験誤差範囲内の $1 \mathrm{~g} / \mathrm{m}^{2}$ 以下であり極め て小さい。 $800^{\circ} \mathrm{C}$ 以上の温度では、 $100^{\circ} \mathrm{C}$ とつき 10 倍の割合で酸化量が增光る。

Table 3 にX線回折による表層および䟝離スケ ール層の同定結果を示す。すべての試料で、 $\mathrm{TiO}_{2}$ 、 $\mathrm{Al}_{2} \mathrm{O}_{3}$ が認められ、スケールはこの 2 つの酸化物 によって形成されていることがわかる。そして。 温度が低いときには母材の TiAl の回折強度が強 く、温度が高くなるに連れ、 $\mathrm{TiO}_{2} 、 \mathrm{Al}_{2} \mathrm{O}_{3}$ の回折強 度が強くなっている。槑離スケールは主として $\mathrm{TiO}_{2}$ からできており、若干 $\mathrm{Al}_{2} \mathrm{O}_{3}$ が混しっって る。また、 $800^{\circ} \mathrm{C}$ 以上では酸化物以外に $\mathrm{Ti}_{3} \mathrm{Al}$ 層。 認められる。

975ㄷ までの TiAl の酸化挙動は、放物線則によ く従ちといわれていることから"11、今回のデータ を基に TiAlの酸化の活性化エネルギーを求め

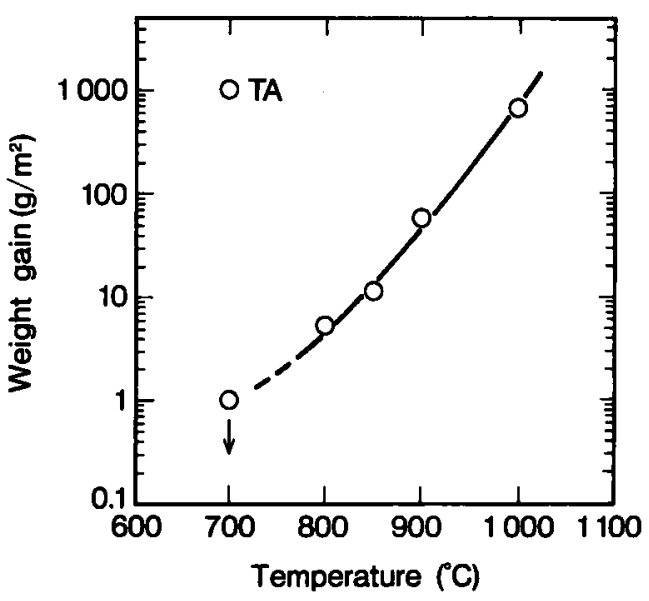

Fig. 3. Weight gain of TA in isothermal oxidation for $96 \mathrm{~h}$.

Table 3. Identified oxides by $\mathrm{X}$-ray diffraction in isothermal oxidation.

\begin{tabular}{|c|c|c|}
\hline Temperature & Surface & Spallation scale \\
\hline $700^{\circ} \mathrm{C}$ & $\begin{array}{l}\mathrm{TiAl}(\mathrm{S}) \\
\mathrm{TiO}_{2} \\
\mathrm{Al}_{2} \mathrm{O}_{3}\end{array}$ & \\
\hline $800^{\circ} \mathrm{C}$ & $\begin{array}{l}\mathrm{TiAl}(\mathrm{S}) \\
\mathrm{Ti}_{3} \mathrm{Al}(\mathrm{W}) \\
\mathrm{TiO}_{2} \\
\mathrm{Al}_{2} \mathrm{O}_{3}\end{array}$ & \\
\hline $850^{\circ} \mathrm{C}$ & $\begin{array}{l}\mathrm{TiAl} \\
\mathrm{Ti}_{3} \mathrm{Al}(\mathrm{W}) \\
\mathrm{TiO}_{2} \\
\mathrm{Al}_{2} \mathrm{O}_{3}\end{array}$ & \\
\hline $900^{\circ} \mathrm{C}$ & $\begin{array}{l}\mathrm{TiAl}(\mathrm{S}) \\
\mathrm{Ti}_{3} \mathrm{Al}(\mathrm{W}) \\
\mathrm{TiO}_{2} \\
\mathrm{Al}_{2} \mathrm{O}_{3} \\
\end{array}$ & $\begin{array}{l}\mathrm{TiO}_{2}(\mathrm{~S}) \\
\mathrm{Al}_{2} \mathrm{O}_{3}\end{array}$ \\
\hline $1000^{\circ} \mathrm{C}$ & $\begin{array}{l}\mathrm{TiO}_{2}(\mathrm{~S}) \\
\mathrm{Al}_{2} \mathrm{O}_{3}\end{array}$ & $\begin{array}{l}\mathrm{TiO}_{2}(\mathrm{~S}) \\
\mathrm{Al}_{2} \mathrm{O}_{3}\end{array}$ \\
\hline
\end{tabular}

1) $700{ }^{\circ} \mathrm{C}:$ No spallation, $800{ }^{\circ} \mathrm{C}, 850^{\circ} \mathrm{C}:$ No analysis 2) (S) : Strong, (W) :Weak

た。Fig.4は、酸化增量から求めた放物線速度定数 の温度依存性をフレニウスブロットで表わしたす のである。 $800^{\circ} \mathrm{C}$ から1000足のデータの㑯きから

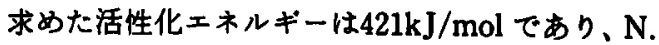




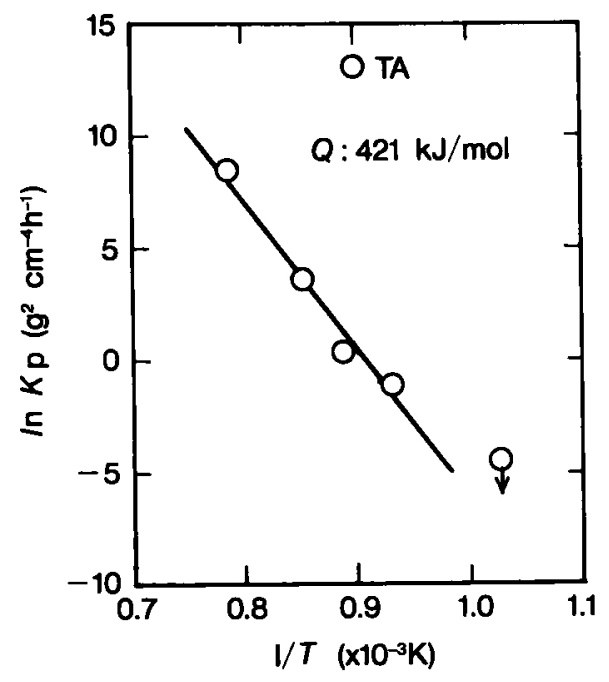

Fig. 4. Parabolic rate constants and activation energy of oxidation $(Q)$ of TA.

S. Choudhury が求めた值 $(423 \mathrm{~kJ} / \mathrm{mol}){ }^{12)} \mathrm{G}$. Welsch らが求めた值 $(419 \mathrm{~kJ} / \mathrm{mol})$ とほぼ等しい 值を示している11)。この值は、G. Welsch らによ れぱ、純然たる $\mathrm{Al}_{2} \mathrm{O}_{3}$ 中の酸素胁散の活性化エネ ルギーより小さく、ルチルやアルミナの粒界など の速い酸素拡散の活性化エネルギーとの中間の值 になっていると説明している。本実験です TiAl の酸化スケールは、 $\mathrm{Al}_{2} \mathrm{O}_{3}$ 単相ではなく、 $\mathrm{TiO}_{2}$ 居を 含んたるのとなっており、得られた活性化ェネル ギーあ、その影篔を受けたすのになっているのか すしれない。いずれにしても、いかに健全な $\mathrm{Al}_{2} \mathrm{O}_{3}$ 層を形成することができるかが、TiAl の耐酸化性 を改善ナる一つの大きな鍵となっているといえ る。

\section{1 .2 緤返 L酸化特性}

Photo. 3 に TA 材の $700^{\circ} \mathrm{C} と 900^{\circ} \mathrm{C} に お け る$ 繰 返し酸化試駼後の外钼を示す。700"Cでは、連続酸 化試験の時と同様、表面が黒色になっているだけ であり、酸化の進行は認められない。900゚では、

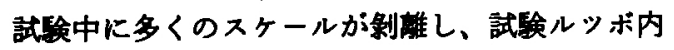
に堆積した。試咉後の試梌片に残存したスケール は、厚い部分では浱黄色を呈しており、薄くなる に連れ黄色から白色へと变わっている。またこー ナー部などの衤応力が高い部分は、黒色でスケー ルがすっとも薄くなっている。

綝返し酸化試倹における酸化増量と、熱天科に よる900 $\mathrm{C}$ 連続酸化試験の結果をFig. 5 に示

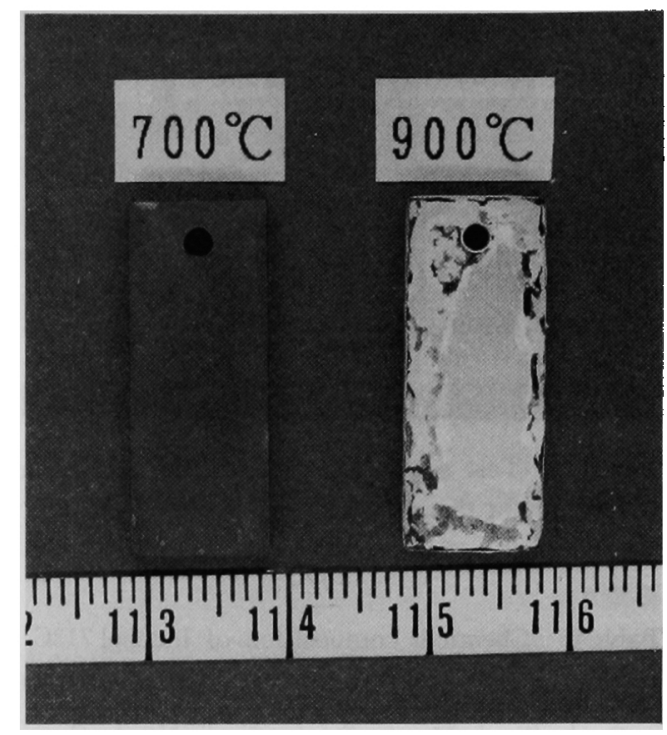

Photo. 3. Test specimens of TA after cyclic oxidation for $96 \mathrm{~h}$.

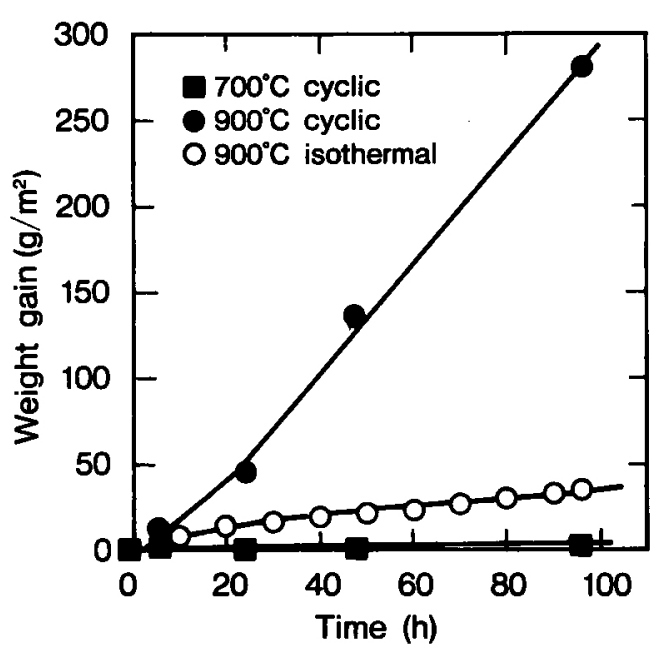

Fig. 5. Weight gain of TA in cyclic oxidation.

す。700 Cの絽返し酸化による酸化增量は、連続酸 化と同棣、実験詰差範囲内である。900 Cの時は、 連続酸化がほぼ放物線則に従らのに対し、綝返し 酸化では直線則となっている。また96時間後の酸 化增量も、連続酸化のときの約 7 倍であり、綝り 返しにより酸化が著しく加速されている。

Table 4 には、表居および剝離スケール層のX 
Table 4. Identified oxides by $\mathrm{X}$-ray diffraction in cyclic oxidation.

\begin{tabular}{c|l|c}
\hline Temperature & Surface & Spallation scale \\
\hline \multirow{2}{*}{$700 \mathrm{C}$} & $\mathrm{TiAl}(\mathrm{S})$ & \\
& $\mathrm{TiO}_{2}$ & \\
& $\mathrm{Al}_{2} \mathrm{O}_{3}$ & \\
\hline \multirow{2}{*}{$900 \mathrm{C}$} & $\mathrm{TiO}_{2}$ & $\mathrm{TiO}_{2}$ \\
& $\mathrm{Al}_{2} \mathrm{O}_{3}$ & $\mathrm{Al}_{2} \mathrm{O}_{3}$ \\
\hline
\end{tabular}

1) $700^{\circ} \mathrm{C}:$ No spallation
線回折による同定結果を示す。生成した酸化物は $\mathrm{TiO}_{2}$ と $\mathrm{Al}_{2} \mathrm{O}_{3}$ であり、連続酸化と同様、この 2 種 の酸化物によりスヶールが形成されていることか わかる。

\subsection{3 表層锶察}

Photo. 4 と Photo. 5 に $900^{\circ} \mathrm{C}$ における連続酸 化および絽返し酸化試馀後の断面 SEM 像および 線分析結果を示す。連続酸化試会は、表面スヶー

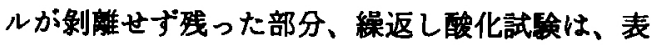

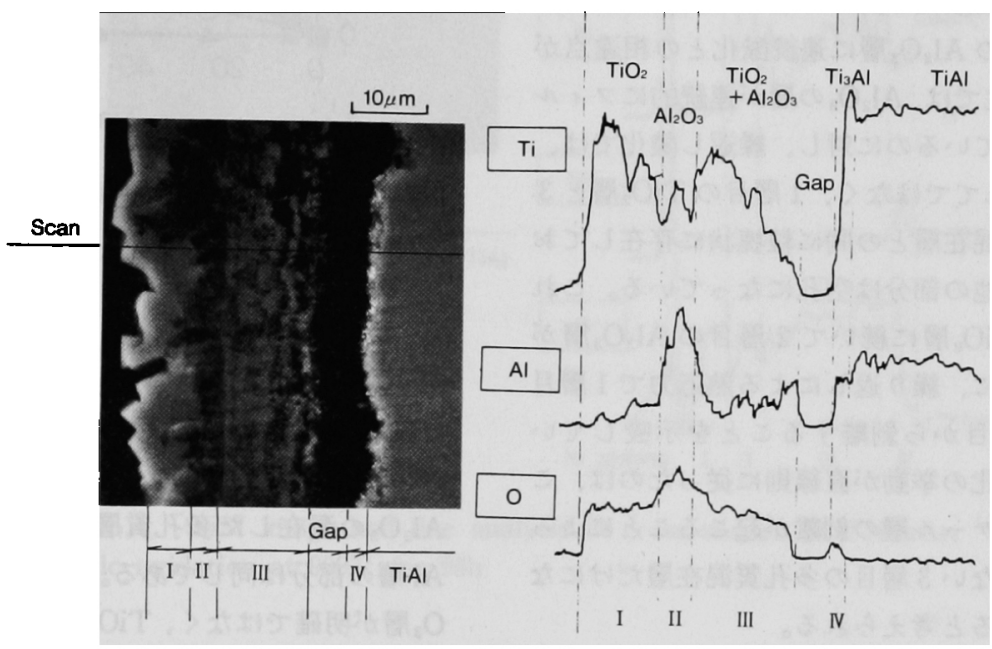

Photo. 4. SEM image and line analysis in cross section of TA after isothermal oxidation at $900^{\circ} \mathrm{C}$ for $96 \mathrm{~h}$.

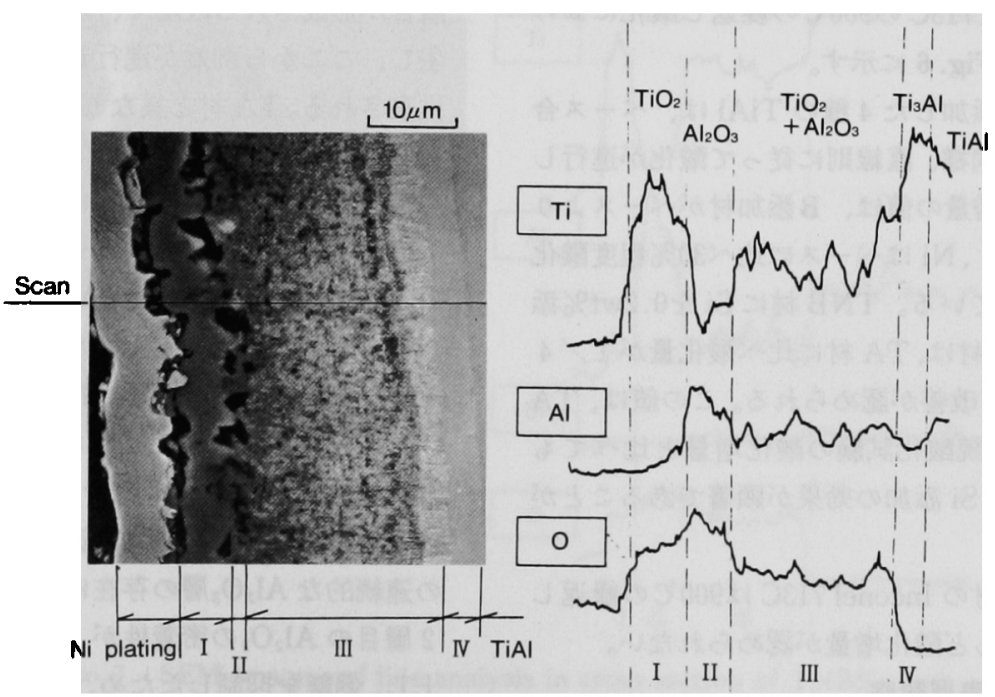

Photo. 5. SEM image and line analysis in cross section of TA after cyclic oxidation at $900^{\circ} \mathrm{C}$ for $96 \mathrm{~h}$. 
面の黄色を呈したスケール周の部分である。

連続酸化試䀫におけるスケール樓造は、今まで と報告されだ),7構造と同じであり、表面外側から 順に、 $\mathrm{TiO}_{2}$ 屏、 $\mathrm{Al}_{2} \mathrm{O}_{3}$ 層と $\mathrm{TiO}_{2}$ と $\mathrm{Al}_{2} \mathrm{O}_{3}$ の混在し た多孔質庴、および $\mathrm{Ti}_{3} \mathrm{Al}$ となっている。連続酸 化では、このよ5にはっきりとした 4 層からなる スケールが形成されている。なお写真では切断時 に発生したと思われる㩐間か、3 層目と 4 層目の 間に認められる。

一方綝返し酸化試検におけるスケール構造は、 基本的には連続酸化と同し 4 凰から構成されてい るが、2 層目の $\mathrm{Al}_{2} \mathrm{O}_{3}$ 居に連続酸化との相違点が ある。連続酸化では、 $\mathrm{Al}_{2} \mathrm{O}_{3}$ の居が連続的にフィル ム状に存在しているのに対し、絽返し酸化では、 $\mathrm{Al}_{2} \mathrm{O}_{3}$ が面としてではなく、1㬝目の $\mathrm{TiO}_{2}$ 層と 3 層目の多孔質混在㕌との間に粒塊状に存在してお ク、2 層目の他の部分は空孔になっている。これ は 1 層目の $\mathrm{TiO}_{2}$ 居に続いて 2 層目の $\mathrm{Al}_{2} \mathrm{O}_{3}$ 層か 形成される際に、綠り返しによる熱応力で1層目 るしくは 2 層目から䟝離することを示㖫してい る。綝返し酸化の举動が直線則に従ったのは、こ の表層部のスヶール層の剂離が起こることによっ て、保㩐性のない3居目の多孔質混在層たけになな ったためであると考えられる。

\section{2 合金元来添加材の綵返し酸化挙㲜}

\subsection{1 綵返し酸化特性}

$\mathrm{Ni}, \mathrm{B}, \mathrm{Si}$ を単独/袮合添加した 4 種および比 较材の Inconel $713 \mathrm{C}$ の $900^{\circ} \mathrm{C}$ の綝返し酸化におけ る酸化増量を Fig. 6 に示す。

合金元素を添加した 4 種の TiAl は、ベース合 金の TA 材と同様、直線則に従って酸化が進行し ている。酸化增量の値は、B添加材がベースょり わずかに少なく、Niはベースに比べ30\%程度酸化 量が多くなっている。TNB材に Si を0.2wt\%添 加した TNBS 材は、TA 材に比へ酸化量が $1 / 4$ と、耐酸化性の改善が認められる。この值は、TA 材の $9000^{\circ} \mathrm{C}$ の連続酸化試徐の酸化增量と比べても 約 2 倍であり、 $\mathrm{Si}$ 添加の刘果が顕著であることが わかる。

一方、比較材の Inconel $713 \mathrm{C}$ は900'Cの綠返し 酸化でるほとんど酸化增早が認められない。

\subsection{2 表扈镜案}

Photo. 6 とPhoto. 7 に TN 材とTNBS 材の 繰返し酸化試検後の断面 SEM 像と線分析結果を

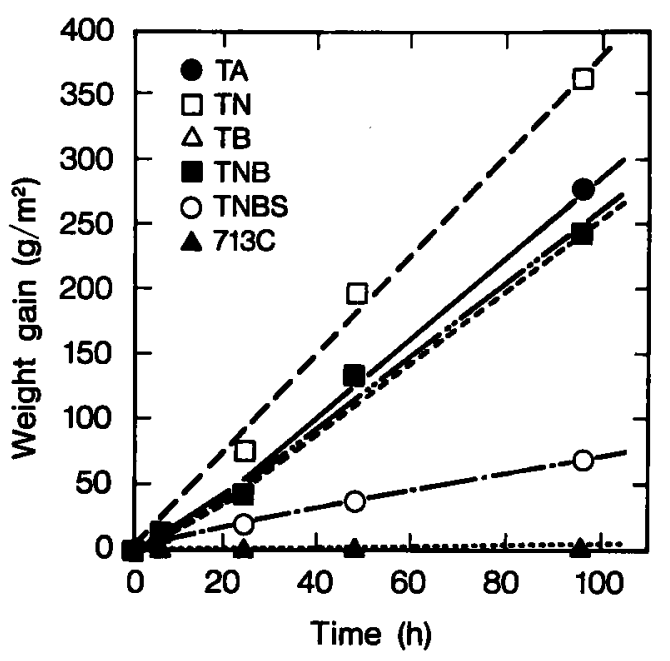

Fig. 6. Weight gains of TiAl compounds in cyclic oxidation at $900^{\circ} \mathrm{C}$.

示す。

$\mathrm{Ni}$ を添加した TN 材のスケール構造は、ベー スの $\mathrm{TA}$ 材と 1 層目の $\mathrm{TiO}_{2}$ 層、3層目の $\mathrm{TiO}_{2}$ と $\mathrm{Al}_{2} \mathrm{O}_{3}$ の混在した多孔質層、および 4 凰目の $\mathrm{Ti}_{3}$ $\mathrm{Al}$ 層の部分は同じである。しかし、2 層目の $\mathrm{Al}_{2}$ $\mathrm{O}_{3}$ 層が明確ではなく、 $\mathrm{TiO}_{2}$ 層の中に粒塊状の $\mathrm{Al}_{2}$ $\mathrm{O}_{3}$ が点在するとい5形態を示している。また 1 層 目と 2 層目の界面付近には吵間が認められる。こ れは TA 材と同様、1 層目が形成され、続いて 2 層目が形成される段階で、熱応力による割れが発 生し、ここから剩離が進行している状態であると 推察される。TA材と異なり2 層目に $\mathrm{TiO}_{2}$ 層が存 在するのは、既に割れている1層目のスヶールか ら酸秦が侵入し、優先的に次の 1 䅉目となる $\mathrm{TiO}_{2}$ の成長が始まったのか、 $\mathrm{Ni}$ を添加したこと によるるのかは定かではない。

Si を添加した TNBS 材のスケール構造は、連 続酸化の構造に似ている。すなわち、2 層目の $\mathrm{Al}_{2}$ $\mathrm{O}_{3}$ 層が連続的に面として存在している。本研究の 調查籍囲ではスケール内での Si の存在が認めら れなかったため、詳細な原因は不明であるが、こ の連続的な $\mathrm{Al}_{2} \mathrm{O}_{3}$ 居の存在は、1 居目の $\mathrm{TiO}_{2}$ 層と 2 層目の $\mathrm{Al}_{2} \mathrm{O}_{3}$ の密着性が、 $\mathrm{Si}$ の添加によって向 上し、跈離を抑制したため、 $\mathrm{Al}_{2} \mathrm{O}_{3}$ 㬝の成長が十分 になされたと考えられる。これは、TA材、TN 材 では認められなかった、3首目の割れからす隻付 


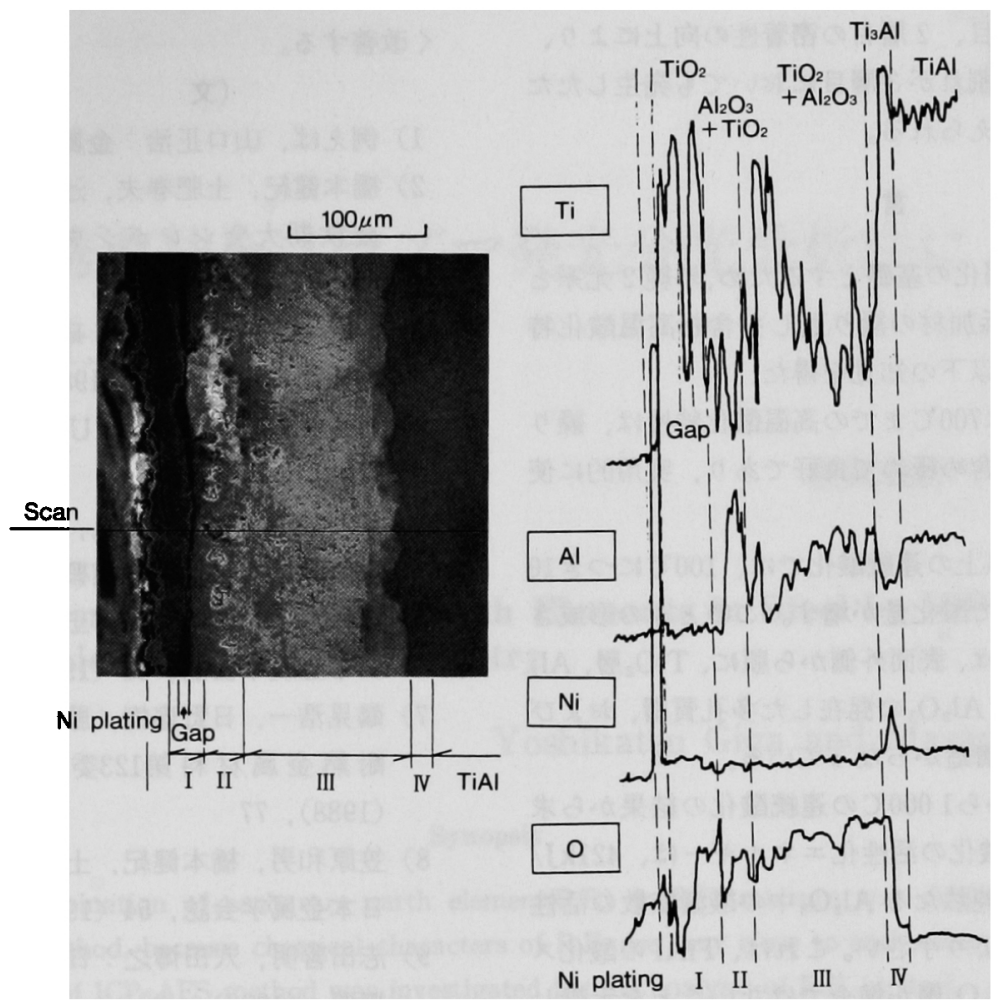

Photo. 6. SEM image and line analysis in cross section of $\mathrm{TN}$ after cyclic oxidation at $900^{\circ} \mathrm{C}$ for $96 \mathrm{~h}$.

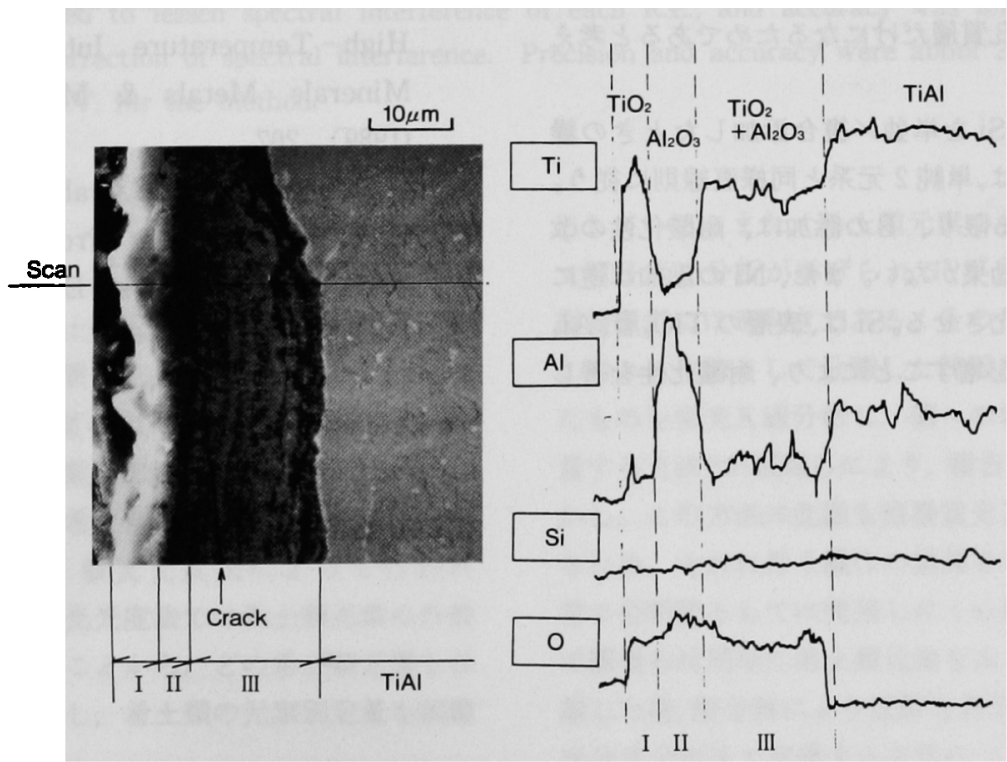

Photo. 7. SEM image and line analysis in cross section of TNBS after cyclic oxidation at $900^{\circ} \mathrm{C}$ for $96 \mathrm{~h}$. 
けられ、1層目、2 㬝目の密着性の向上により、 熱応力による割れが 3 層目にお゙いてす発生したた めであると考えられる。

\section{4. 桔}

TiAl の実用化の基硤とするため、単純 2 元系と $\mathrm{Ni}, \mathrm{B}, \mathrm{Si}$ の添加材の繰り返しを含を高温酸化特 性を調査し、以下の知見を得た。

（1） TiAl $700^{\circ} \mathrm{C}$ まの高温酸化特性は、綝り 返し環境下を含め極めて良好であり、実用的に使 用できる。

(2) $800^{\circ} \mathrm{C}$ 以上の連続酸化では、 $100^{\circ} \mathrm{C}$ につ 10 倍程度の割合で酸化量が增す。このときの形成さ れるスケールは、表面外側から㮌に、 $\mathrm{TiO}_{2}$ 層、 $\mathrm{Al}_{2}$ $\mathrm{O}_{3}$ 層、 $\mathrm{TiO}_{2}$ と $\mathrm{Al}_{2} \mathrm{O}_{3}$ の混在した多孔質層、および $\mathrm{Ti}_{3} \mathrm{Al}$ の 4 層構造からなっている。

(3) $800^{\circ} \mathrm{C}$ から $1000^{\circ} \mathrm{C}$ の連続酸化の結果から求 めた TiAl の酸化の活性化エネルギーは、421kJ/ $\mathrm{mol}$ であり、純然たる $\mathrm{Al}_{2} \mathrm{O}_{3}$ 中の酸素抾散の活性 化ェネルギー上り小さい。これは、TiAlの酸化ス ケール中の $\mathrm{Al}_{2} \mathrm{O}_{3}$ 居が健全ではないことを示唆し ている。

（4）綝り返し環境下では酸化は著しく加速さ れ、その挙動は直線則に従う。これは絽り返しに よる熱応力で、スケール外側の $\mathrm{TiO}_{2}$ 層、 $\mathrm{Al}_{2} \mathrm{O}_{3}$ 屏 が剥離し、多孔質層たけになるためであると考え られる。

（5） Ni， B， Si を単独/袮合添加したときの繰 返し酸化挙動は、単純 2 元系と同様直線則に従 5。 酸化増量でみる限り、Bの添加は、耐酸化性の改 善にほとんど効果がない。また、Ni の添加は逆に 耐酸化性を劣化させる。 $\mathrm{Si}$ は、表居の $\mathrm{TiO}_{2}$ 居、 $\mathrm{Al}_{2}$ $\mathrm{O}_{3}$ 居の密着性を増すことにより、耐酸化性を著し
く改善する。

（文献）

1）例之ば，山口正治：金属，59（1989），49

2）橋本健紀，土肥春夫，辻本得蔵：日本金属学 会秋期大会シンポジム講演予稿, $\mathrm{S}_{6} \cdot 18$ (1986), 169

3）磯部 晋, 野田俊治：日本金属学会秋期大会 一般講演概要，200（1987），312

4) Blackburn et al. : U.S.Patent 4294615 , (1981)

5）野田陖治，飯久保知人，磯部 晋：日本金属 学会秋期大会一般講演概要，（1988），498

6）笠原和男，橋本健紀，土肥春夫，辻本得蔵： 日本金属学会誌, 53 (1989), 58

7）鶴見浩一，日野春樹，藤岡順三，西山幸夫： 耐熱金属材料第123委員会研究報告, 29 (1988), 77

8）笠原和男，橋本健紀，土肥春夫，辻本得蔵： 日本金属学会誌, 54 (1990), 948

9）志田善明，穴田博之：日本金属学会秋期講演 概要，(1990），274

10）池松陽一，花村年裕，森川博文，谷野満，

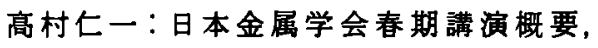
(1991), 196

11) G.Welsch, A.I.Kahveci : Oxidation of High-Temperature Intermetallics, The Minerals, Metals \& Materials Society, (1989), 207

12) N.S.Choudhury, H.C.Graham, J.W.Hinze : Proc. of Symp. on Properties of High Temperature Alloys, Electrochem. Soc. Pro., 77-1 (1976), 668 